Contents lists available at \ournal IICET

JPPI (Jurnal Penelitian Pendidikan Indonesia)

ISSN: 2502-8103 (Print)ISSN: 2477-8524(Electronic)

\title{
Manajemen strategi FAB Enterprises dalam membangun kolaborasi bisnis
}

\author{
Fausta Ari Barata*) \\ Universitas 17 Agustus 1945, Surabaya, Indonesia
}

\begin{tabular}{l} 
Article Info \\
\hline Article history: \\
Received Mar $30^{\text {th }}, 2021$ \\
Revised Apr $27^{\text {th }}, 2021$ \\
Accepted May $27^{\text {th }}, 2021$ \\
\hline
\end{tabular}

\section{Keyword:}

Manajemen strategi

Kolaborasi bisnis

\begin{abstract}
Konsep bisnis sudah tidak lagi menggunakan pemikiran independensi melainkan berevolusi menjadi interpendensi. Dimana bisnis bukan sekedar dan selalu mengarah pada kompetisi akan tetapi menuju pada kolaborasi. Kolaborasi bisnis menjadi pilihan optimal dalam menjalankan strategi bisnis internasional. Fab Enterprises merupakan salah satu perusahaan yang menerapkan konsep kolaborasi dimana terdapat perusahaan partner kolaborasi diantaranya PT. Carestar/harvestar, PT. Astarika Stuwarindo, pt. Alam Sejati Trans, dan PT. Serunting Sriwijaya. Sebagai perusahaan yang bergerak dibidang logistic skala internasioanl, strategi bisnis kolaborasi yang dilakukan mendongkrak kinerja dan mendapatkan respon positif dari beberapa pihak. Artikel ini bermaksud mengupas bagaimana manajemen strategi yang diterapkan Fab Enterprises dalam menjalin hubungan kerjasama yang baik sehingga apa yang menjadi visi, misi, dan tujuannya dapat tercapai. Penelitian ini menggunakan pendekatan kualitatif dengan jenis studi kasus. Peneliti mengambil data melalui wawancara mendalam kepada informan, observasi, dan pengambilan dokumentasi. Analisis data menggunakan teori Milles dan Haberman, yaitu model analisis interaktif, dimulai dari kondensasi data, penyajian data, dan verifikasi data/penarikan kesimpulan. Hasil penelitian menyatakan bahwa, manajemen strategi yang diterapkan dalam membangun kolaborasi bisnis melalui tiga tahapan. Yang pertama perumusan strategi berdasar audit internal dan eksternal perusahaan, berdasar visi misi dan tujuan perusahaan sehingga menghasilkan strategi membentuk kepercayaan dan rekanan bisnis yang baik. Kedua implementasi strategi yang didasarkan pada alokasi sumber daya yang efektif, membuat kebijakan pelaksanaan, serta memberikan motivasi. Ketiga adalah evaluasi strategi dengan melakukan monitoring/pengamatan selama proses berjalan dan secara berkala.
\end{abstract}

(C) 2021The Authors. Published by IICET.

This is an open access article under the CC BY-NC-SA license

(https://creativecommons.org/licenses/by-nc-sa/4.0)

\section{Corresponding Author:}

Fausta Ari Barata

Universitas 17 Agustus 1945, Surabaya

Email: fausta.untagsby@fab-Enterprises .com

\section{Pendahuluan}

Lingkungan bisnis yang dinamis dan terus berubah memberikan dampak pada hubungan antar perusahaan yang mengarah pada saling interdependensi. Pergeseran tersebut melahirkan berbagai pemikiran pada model pengelolaan bisnis berdasarkan kemitraan. Kim dan Maurborgne (2006) menyatakan, konsep persaingan sudah tidak lagi diibaratkan dengan samudra merah yang berdarah-darah, akan tetapi diganti dengan samudra biru yang mampu menciptakan ruang-ruang pasar tanpa pesaing. Bleeke dan Ernst (1993), kolaborasi dianggap sebagai alat negosisasi dan konsep yang paling tepat. Sehingga untuk saat ini, strategi kolaborasi 
semakin lebih meningkat dibandingkan dengan strategi kompetisi. Kolaborasi dalam ruang bisnis juga menjadi alternatif daripada strategi kompetisi. Munt (2003) menyampaikan bahwa kolaborasi merupakan working together dalam mencapai tujuan yang diinginkan bersama untuk menghasilkan output yang berkualitas dan berkelanjutan. Morsink dkk (1991) menyebut kolaborasi sebagai usaha bersama dalam melakukan perencanaan, pelaksanaan, dan evaluasi program yang telah disepakati bersama untuk mencapai tujuan yang diinginkan bersama.

Kolaborasi merupakan pilihan yang optimal dalam menjalankan strategi bisnis. Menjalin kerjasama yang baik antar perusahaan juga tidak semudah yang dibayangkan mengingat masing-masing memiliki karakter dan tujuan yang berbeda. Dengan dibutuhkan peta konsep kerjasama matang, komitmen, dan keterbukaan yang kuat, tujuan bersama beberapa perusahaan tersebut dapat dicapai. Kolaborasi bisnis memerlukan manajemen strategi dimana dengan pengelolaan strategi yang tepat dan cermat dalam menjalankan kolaborasi akan dapat menciptakan networking/ jalinan kerjasama yang baik, sehingga apa yang menjadi tujuan bersama akan lebih mudah untuk dicapai.

David (2010) menyatakan, manajemen strategi sebagai ilmu dalam merumuskan, melaksanakan, serta mengevaluasi keputusan-keputusan lintas fungsi yang memungkinkan organisasi dapat mencapai tujuannya. Manajemen strategi juga bisa diartikan sebagai sejumlah keputusan serta tindakan yang mengarah pada penyusunan strategi yang paling efektif dalam upaya mencapai sasaran perusahaan (Lawrence dan William, 1998). Manajemen strategi membutuhkan owner yang memiliki komitmen yang tinggi dalam menjaga jalinan kerjasama yang dibentuk. Visi misi dan tujuan bersama yang ingin dicapai juga harus jelas, strategi yang dipilih harus tepat, dan juga sumber daya manusia harus dikelola dengan baik, serta perlu adanya monitoring sebagai bentuk evaluasi dalam menjalankan kerjasama.

Kerjasama bisnis yang baik dipraktekan oleh perusahaan Fab Enterprises dengan perusahaan PT. Carestar/Harvestar, PT. Astarika Stuwarindo, PT. Alam Sejati Trans, PT. Serunting Sriwijaya, CV. Kalijaga, dan PT. Gita Mandiri Trans. Fab Enterprises merupakan perusahaan 4PL yang mengarah pada jasa Logistic, Trading, Supply Chain, dan Consultant. Fab Enterprises hadir untuk ikut meramaikan pelayanan jasa khususnya dibidang Logistic, Trading, Supply Chain, dan Consultant dimana dewasa ini masih didominasi oleh kecenderungan 3PL. Manajemen strategi bisnis dengan rekanan berkomitmen dalam memberikan layanan yang baik dan tepat waktu. Strategi kolaborasi diterapkan oleh perusahaan Fab Enterprises dengan mitra perusahaan yang memiliki spesifikasi sendiri-sendiri. Jalinan kerjasama dan kolaborasi yang baik antara Fab Enterprises dengan mitra menjadikan prestasi luar biasa. Dimana Fab Enterprises yang tergolong perusahaan baru mampu memberikan kepercayaan kepada partnernya untuk menjalin kerjasama dalam menjalankan visi misinya serta kepuasan pengguna jasa. Pengelolaan strategi bisnis yang dilakukan Fab Enterprises urgen karena mendukung keberlangsungan kerjasama dengan perusahaan partner dan mempermudah mencapai tujuan perusahaan.

\section{Manajemen Strategi}

Istilah manajemen strategi merupakan gabungan dua kata yang masing-masing memiliki makna sendiri, yaitu dari kata manajemen dan strategi. Manajemen didefinisikan sebagai kemampuan serta keterampilan khusus dalam melakukan suatu kegiatan baik bersama orang lain atau melalui orang lain untuk mencapai tujuan organisasi (Sudjana, 2000). Nawawi (2005) menjelaskan manajemen sebagai kemampuan manajer dalam mendayagunakan bawahannya melalui kegiatan dan mengembangkan kerja sama untuk mencapai tujuan organisasi secara efektif dan efisien. Manajemen juga diartikan sebagai proses dalam merencanakan, mengorganisasi, memimpin, serta mengendalikan upaya anggota organisasi, dan menggunakan seluruh sumber daya organisasi lainnya untuk mencapai tujuan organisasi (Siswanto, 2005). Strategi menurut Wheelen dan Hunger (2003), suatu rumusan perencanaan yang komprehensif terkait bagaimana suatu organisasi akan mencapai visi, misi dan tujuannya, melalui strategi suatu organisasi akan mampu dalam memaksimalkan keunggulan kompetitif dan meminimalkan keterbatasan bersaing. David (2010) mendefinisikan manajemen strategi sebagai ilmu tentang bagaimana merumuskan, mengimplemetasikan, serta mengevaluasi keputusan-keputusan lintas fungsi yang memberikan harapan organisasi untuk mencapai tujuannya. Manajemen strategi juga bisa diartikan sebagai sejumlah keputusan dan tindakan yang mengarah pada penyusunan strategi yang efektif untuk membantu mencapai sasaran perusahaan (Lawrence dan Wiliam, 1998). Manajemen strategi penting untuk membantu perusahaan merumuskan strategi-strategi yang paling baik melalui penggunaan pendekatan terhadap pilihan strategi yang lebih sistematis, logis dan rasional. Manajemen strategi dalam sebuah perusahaan yang dilaksanakan secara efektif akan mendorong kinerja dan mencapai tujuannya.

Manajemen strategi terdiri dari tiga tahapan dimulai dengan perumusan atau memilih pola tindakan utama untuk mewujudkan visi dan misi. Tahap kedua adalah bagaimana Langkah mewujudkan visi misi. Tahap ketiga evaluasi untuk mengetahui apakah Langkah yang diambil sesuai dengan perumusan strategi yang 
ditetapkan di awal. David (2010) mengungkapkan bila, dalam manajemen strategi meliputi pertama, perumusan strategi yaitu langkah-langkah dalam perumusan strategi meliputi kegiatan mengembangkan visi dan misi, melakukan analisis internal dan eksternal, menetapkan tujuan-tujuan jangka panjang, menciptakan, mengevaluasi serta memilih strategi. Kemudian langkah yang ke dua yaitu implementasi strategi, meliputi penerapan isu-isu strategi, strategi pemasaran dan keuangan. Tahap yang terakhir yaitu mengukur dan mengevaluasi kinerja. Hunger dan Wheelen (2003) menjelaskan mengenai tahapan manajemen strategi yaitu meliputi tahap pengamatan lingkungan, perumusan strategi, implementasi strategi, dan evaluasi strategi. Pengamatan lingkungan merupakan tahapan pertama sebelum melakukan perumusan strategi.

\section{Kolaborasi Bisnis}

Kolaborasi merupakan proses dimana oranisasi-organisasi mencari solusi secara bersama-sama terhadap permasalahan-permasalahan yang sedang dihadapi dalam rangka mencapai tujuan bersama (Dwiyanto, 2011). Oleh karena itu, dalam menjalin kerjasama kolaborasi visi bersama menjadi suatu dasar dalam merumuskan tujuan, mengalokasikan sumber daya, aktivitas dari masing-masing organisasi, sehingga semuanya memiliki kontribusi dalam bertanggung jawab mewujudkan tujuan bersama (Dwiyanto, 2011). Hager dan Cury (2009) menyebutkan ada delapan bentuk kolaborasi yang diterapkan dalam kerjasama, anatar lain: 1) fully integrated merger, 2) partially integrated merger, 3) joint programe office, 4) jointpartnership with affiliated programming, 5) joint partnership for issue advocacy, 6) joint partnership with the birth of a new formal organization, 7) joint administrative office and back office operations, 8) confederation.

Kolaborasi antar perusahaan yang baik tidak akan terlepas dari bagaimana proses kolaborasi dilakukan. Byrson dkk (2006) membagi proses kolaborasi dalam beberapa bidang, antara lain: pertama, membentuk kesepakatan secara formal terhadap bagian-bagian terkait misi. Kedua, membentuk kepemimpinan dari dalam kolaborasi, yang berwenang terhadap pengelolaan sumber daya serta berkomitmen terhadap pelaksanaan kerjasama. Ketiga, membangun legitimasi. Keempat, membangun kepercayaan. Dan kelima, merencanakan indikator dalam mencapai kesuksesan. Kerangka proses dalam kolaborasi antara lain adalah sebagai berikut: 1) melakukan tawar menawar yang salin memberikan keuntungan kepada semua pihak, 2) membangun kesepakatan secara bersama dalam mencapai tujuan masa depan, 3) menjalankan apa yang sudah diputuskan dan dijanjikan secara bersama, dan 4) melakukan penilaian terhadap seluruh proses (Ann Marie Thomson, James L. Perry, 2006). Thomsan dan Miller (2002) menyatakan ada empat dimensi proses kolaborasi dalam kerjasama antara lain: pertama, berkaitan dengan pemerintah yaitu dengan membuat keputusan dan kesepakatan bersama. Kedua, melibatkan berbagai peran serta berbagai dukungan dalam menjalankan manajemen, seperti dukungan keuangan, fasilitas dan lain sebagainya. Ketiga, adanya kemandirian. Beberapa hal juga harus diperhatikan dalam proses kolaborasi antarorganisasi, sehingga apa yang menjadi visi, misi, dan tujuan yang diharapkan bisa tercapai, antara lain seperti bagaimana mengelola tujuan/goals sebagai alasan utama dalam berkolaborasi, adanya kompromi dalam mengatasi berbagai perbedaan baik dari gaya kerja individu, kultur, maupun nilai-nilai organisasi, membangun komunikasi yang efektif untuk memahami makna yang diinginkan pihak lain serta menghindari adanya kesalahfahaman, democracy and equality, adanya kekuatan dan kepercayaan (power and trust), dan adanya komitmen bersama (Huxham, Vangen, 1996).

\section{Metode}

Penelitian ini bertujuan untuk mengetahui Pengaruh Manajemen Strategi FAB Enterprises dalam Kolaborasi Bisnis, dengan menggunakan analisis data kualitatif. Adapun alasan kenapa dipilih metode kualitatif adalah, karena masalah penelitianini masih belum jelas atau atau belum ada data yang cocok tentang masalah yangakan diteliti. Oleh karena itu peneliti terjun langsung ke lapangan untukmelakukan eksplorasi terhadap objek penelitian. Dengan memfokuskan padatujuan mengenai yakni Manajemen Strategi FAB Enterprises dalam kolaborasi bisnis, serta faktor yang mempengaruhidari objek penelitian, dimana objek dari penelitian ini adalah Pelayanan LogistikPada Pendekatan kualitatif dipilih dengan tujuan untuk mendapatkan gambaran secara mendalam mengenai pengelolaan strategi yang dilakukan oleh Fab Enterprises dalam membangun jalinan kerjasama demi meraih suatu tujuan yang diharapkan. Sedangkan apabila ditinjau dari sifat-sifat datanya, maka penelitian initermasuk ke dalam penelitian kualitatif (kualitatif research) atau naturalistik.Disebut kualitatif, karena sifat data yang dikumpulkannya bercorak kualitatif,bukan kuantitatif yang menggunakan alat-alat pengukur yang bermaksud untukmemahami fenomena tentang apa yang dialami oleh subjek penelitian misalnyaperilaku, persepsi, motivasi, tindakan dan lain-lain secara holistik, dan dengancara deskripsi dalam bentuk kata-kata dan bahasa, pada suatu konteks khususyang alamiah dan dengan memanfaatkan berbagai metode alamiah.(muhadjir, 2002).

Sumber data dalam penelitian ini menggunakan data primer dan data sekunder. Data primer merupakan data yang diperoleh dalam bentuk kata-kata dan perilaku subyek yang berkaitan dengan pengelolaan strategi yang diterapkan oleh perusahaan Fab Enterprises dalam membangun kolaborasi bisnis dengan para partnernya. 
Data sekunder merupakan data yang diperoleh dari dokumen, foto-foto, dan benda-benda yang digunakan sebagai pelengkap data primer (Sugiyono, 2014). Pengambilan data primer dan sekunder Pemilihan informan dalam penelitian kualitatif dilakukan dengancara snowball sampling yakni informan kunci akan menunjuk orang-orangyang mengetahui masalah yang akan diteliti untuk melengkapiketerangannya dan orang-orang yang ditunjuk akan menunjuk orang lainbila keterangan yang diberikan kurang memadai begitu seterusnya, danproses ini akan berhenti jika data yang digali diantara informan yang satudengan yang lainnya ada kesamaan sehingga data dianggap cukup dan tidakada yang baru. Bagi peneliti hal ini juga berguna terhadap validitas datayang dikemukakan oleh para informanmenggunakan teknik pengambilan data sebagaimana yang disampaikan Bogdan (1998), yaitu wawancara mendalam (indepth interview), observasi partisipan (participant observation), dan studi dokumentasi (study of documents), hal tersebut dimaksudkan agar data dapat diperoleh secara holistic dan integrative. Untuk analisis data sebagaimana Milles dan Haberman (1992), yaitu menggunakan model analisis interaktif, yaitu mereduksi data yang terkumpul, kemudian melakukan penyajian data untuk mengambil kesimpulan sementara, dan yang terakhir melakukan verifikasi data atau penarikan kesimpulan akhir.

\section{Hasil dan Pembahasan}

Hasil dari penelitian ini menggambarkan ada tiga tahapan yang dilakukan oleh Fab Enterprises dalam mengelola strategi untuk membangun kolaborasi bisnis dengan beberapa partner usaha. Tiga tahapan pengelolaan tersebut yaitu, perumusan strategi dalam membangun kolaborasi bisnis, implementasi strategi dalam membangun kolaborasi bisnis, dan evaluasi strategi dalam membangun kolaborasi bisnis.

\section{Perumusan Strategi}

Fab Enterprises merupakan perusahaan yang beroperasi dalam melayani jasa Logistic, Trading, Supply Chaint, dan Consultant yang berada di kota Surabaya, Jawa Timur. Pada awal berdirinya perusahaan ini menggunakan badan hukum CV yaitu pada akhir tahun 2011 yang bergerak pada bidang consultant bisnis dan logistic management. Fab Enterprises fokus pada tujuan perusahaan yaitu memberikan kepuasan terhadap pelanggan, sehingga komitmen benar-benar dijaga dalam memberikan layanan yang terbaik dan tepat waktu.

Owner Fab Enterprises awal mula menjalin kerjasama dengan perusahaan lain ketika mendapatkan informasi bahwa ada perusahaan yang membutuhkan partner untuk bekerjasama dalam menangani semua kegiatan logistiknya, yaitu Harvestaryang bekerja dalam bidang produsen tepung terigu (Dok.2018). Owner Fab Enterprises melakukan pertemuan dengan pihak Carestar/Harvestar dalam rangka menjalin komunikasi serta beberapa peluang bisnis yang bisa dijalankan bersama. Persiapan dan strategi matang telah disusun oleh owner Fab Enterprises agar ketika bertemu bisa memaparkan visi misi kerjasama yang ada. Rumusan strategi yang dipersiapkan tentunya didasarkan dari visi, misi, Fab Enterprises. Dimana visinya menjadi perusahaan logistik terintegrasi, terluas, dan terbaik di Indonesia serta mampu memberikan solusi dan handal (DOK.2018). Sementara Misi Fab Enterprises adalah meningkatkan nilai perusahaan melalui jaringan, infrastruktur modern dan diversifikasi usaha dan berkomitmen kepada pelanggan untuk menyediakan layanan yang selalu tepat waktu dan nilai terbaik (DOK.2018). Kolaborasi dengan Carestar/Harvestar melalui strategi membangun kepercayaan partner berhasil dilakukan sehingga kedua perusahaan tersebut berkolaborasi secara baik dan berkelanjutan. Fab Enterprises tidak berhenti pada satu organisasi untuk melebarkan sayapnya. Owner memperkuat bargaining ketika berkolaborasi dengan PT. Astarika yang bergerak dalam bidang bongkar muat barang (DOK.2018). PT. Astarika bergerak dalam bidang jasa dengan memberikan layanan stevedoring untuk generalcargo, steel product, bag cargo, project cargo, bulk cargo, jasa penyewaan reachstacker dan forklift.

Membangun jaringan dengan modal kepercayaan yang kuat dan komunikasi yang baik merupakan strategi bisnis yang dibangun oleh owner Fab Enterprises . Direktur PT. Harvestar menyatakan bahwa kerjasama yang dijalin antara dua pihak didasari dengan adanya kepercayaan yang telah diberikan oleh ownerFab Enterprises . Kepercayaan tidak muncul begitu saja ada melainkan terdapat proses dan beberapa pertimbangan ditambah dengan kinerja owner Fab Enterprises beserta stafnya (INF. 12.09.2018). Staf harvestar menambahkan bahwa kolaborasi bisnis dengan Fab Enterprises terbentuk karena adanya komunikasi baik serta strategi bisnis yang ditunjukkan owner FAB. Komunikasi yang nyaman dan terbuka dirasakan oleh direktur Harvestar. Menurut saya. Owner FAB memiliki kemampuan lobi yang bagus (INF.13.09.2018).

GM di perusahaan PT. Astarika menyatakan bahwa hal yang mendasari adanya kerjasama antara Fab Enterprises dengan PT. Astarika adalah adanya kepercayaan yang telah diperikan oleh Bapak F selaku owner Fab Enterprises kepada Bapak AY. Meskipun kerjasama bisnis antar keduanya memiliki nilai yang sangat besar, akan tetapi kesepakatan yang dibentuk adalah murni karena adanya kepercayaan saja, tanpa adanya formalitas-formalitas secatra tertulis pada setiap transaksi (INF. 05.09.2018). Kolaborasi bisnis Fab Enterprises dengan partner bermaksud memberikan kepuasan pada pelanggan. Strategi membangun kepercayaan dan 
menjalin komunikasi yang baik terhadap partner kerjanya didasarkan pada apa yang tercantum dalam visi dan misi Fab Enterprises, antara lain yaitu dengan menjalin kerjasama yang baik demi meningkatkan nilai perusahaan serta berkomitmen dalam memberikan layanan yang baik dan tepat waktu, serta didasarkan juga dari identifikasi lingkungan internal dan juga eksternal (DOK.2018).

\section{Implementasi Strategi}

Implementasi strategi dalam membangun kolaborasi yang dilakukan owner Fab Enterprises dengan beberapa partner kerjanya adalah dengan menunjukkan komitmen kinerja yang baik (OB.2018). Kinerja yang ditunjukkan oleh para tim Fab Enterprises tidak terlepas dari gaya kepemimpinan owner. Salah satu staf Fab Enterprises menyampaikan bila, karakteristik owner yang positif thinking, dapat dipercaya, menepati janji, menunjukkan beliau memiliki perencanaan yang matang dan penerapan yang baik dalam menjalin bisnis bersama perusahaan lain (INF. 12.09.2018). Ditambahkan lagi oleh Manajer Samudra Indonesia yang menyatakan bila, kinerja owner bersama tim Fab Enterprises sangat bagus serta sesuai dengan harapan partner. Ini mengindikasikan bahwa implementasi strategi bisnis berjalan sangat baik dan tentunya didukung perencanaan yang matang. dengan ownernya selalui sesuai dengan ekspektasi. Manajer Harvestar menyataan bila, we have been doing business for the last 5 years, it's already proven you know that this guy is a performer" (INF. 12.09.2018).

Implementasi strategi Fab Enterprises yang diamati oleh PT. Astarika sebagai partner juga menunjukkan nilai positif atas kinerja Fab Enterprises (Dok.2018), (OB.2018). GM PT. Astarika berpendapat, tidak terdapat permasalahan selama bekerjasama dengan Fab Enterprises, ini menunjukkan perencanaan dan implementasi bisnis mereka sangat baik (INF.12.09.2018). Salah satu staf PT. Astarika menguatkan, bahwa selama menjalin hubungan kerjasama bisnis dengan Fab Enterprises selalu ada SOP yang jelas, profesionalisme tugas, checklist, final checklist personil maupun peralatan. Ini menunjukkan bila Fab Enterprises memang memiliki perencanaan yang sinergi dengan pelaksanaan strategi bisnis (INF.12.09.2018). Kolaborasi yang dilakukan Fab Enterprises dengan para partner yang didasarkan kepercayaan, karakteristik dan pengalaman dari owner, menjadikan strategi bisnis bersama dalam pelaksanaannya menjadi lebih baik.

\section{Evaluasi Strategi}

Langkah akhir dari Fab Enterprises dalam melakukan manajemen strategi bisnis adalah dengan melakukan evaluasi atas Langkah implementasi yang sudah dilakukan. Evaluasi diperlukan untuk melihat apakah strategi yang dilakukan oleh Fab Enterprises dengan beberapa partnernya memberikan kepuasan serta jalinan kerjasama yang baik. Evaluasi strategi juga bisa dilakukan untuk tujuan monitoring strategi bisnis, memotret kelebihan serta kekurangan dalam perencanaan sampai pelaksanaan strategi ketika membangun kolaborasi. Bagaimanakah respon yang diberikan para partner dalam menjalankan bisnis, sehingga apa yang diharapkan dan dirumuskan bersama dapat tercapai.

Evaluasi dalam kolaborasi bisnis dilakukan melalui pengamatan selama melakukan pekerjaan bersamasama serta evaluasi formal yang dilakukan secara berkala. Dari hasil pengamatan yang dilakukan dapat dikatakan bahwa kinerja ditunjukkan oleh Fab Enterprises semakin memberikan kepercayaan yang kuat terhadap partner-partnernya, sehingga kolaborasi tetap survive sampai saat ini (DOK.2018). (OB.2018). Kokoh dan kuatnya kepercayaan tersebut dibuktikan dengan Fab Enterprises mampu menyelasaikan permasalahanpermasalah yang sedang terjadi selama transaksi atau kerjasama berlangsung.

Direktur PT. Carestar menyampaikan bahwa kami berpartner Fab Enterprises terkait ekspor impor gandum. Dalam perjalanan kapal mengalami permasalahan teknis dan untungnya Fab Enterprises Fab Enterprises $\mathrm{S}$ mengatasinya dengan tepat sehingga permasalahan tersebut tidak begitu menggangu proses pengiriman barang yang ada (INF. 12.09.2018). Kemampuan dalam manajemen konflik selama bekerja sama juga dimiliki oleh owner Fab Enterprises. Manajer PT. Astarika menyampaikan bila, owner Fab Enterprises dalam beberapa pertemuan sering memberikan problem solving terhadap kendala-kendala yang dihadapi bersama. (INF. 05.09.2018).

Bentuk evaluasi dalam menjalin hubungan kerjasama ditunjukkan dengan semakin menguatnya ikatan kerjasama Fab Enterprises dengan para partner serta kepuasan pelanggan. Hal mana dapat dirasakan semakin kuat oleh beberapa rekan kerja seperti Carestar dan PT. Astarika. Kolaborasi yang ada semakin kuat dengan bentuk-bentuk evaluasi strategi bisnis yang dilakukan dalam bentuk gathering. OwnerFab Enterprises menyatakan bila, gathering sebenarnya adalah Bahasa pembuka. Di dalamnya kami lebih banyak membicarakan nasib usaha bersama yang dijalankan (INF.05.09.2018). Direktur Carestar menyampaikan bila, keterbukaan dan semangat kekeluargaan menjadikan usaha bersama yang kami lakukan menjadi kuat dan lebih baik. Terbukti kami selama lima tahun lebih saling menguatkan dalam usaha bersama ini (INF.05.09.2018). 


\section{Gambar Hasil Penelitian}

Untuk memudahkan dan meringkas hasil penelitian, maka perlu diberikan gambar untuk mengetahui manajemen strategi Fab Enterprises dalam membangun jaringan bisnis. Penjelasan lebih lanjut dapat dilihat pada gambar 1.

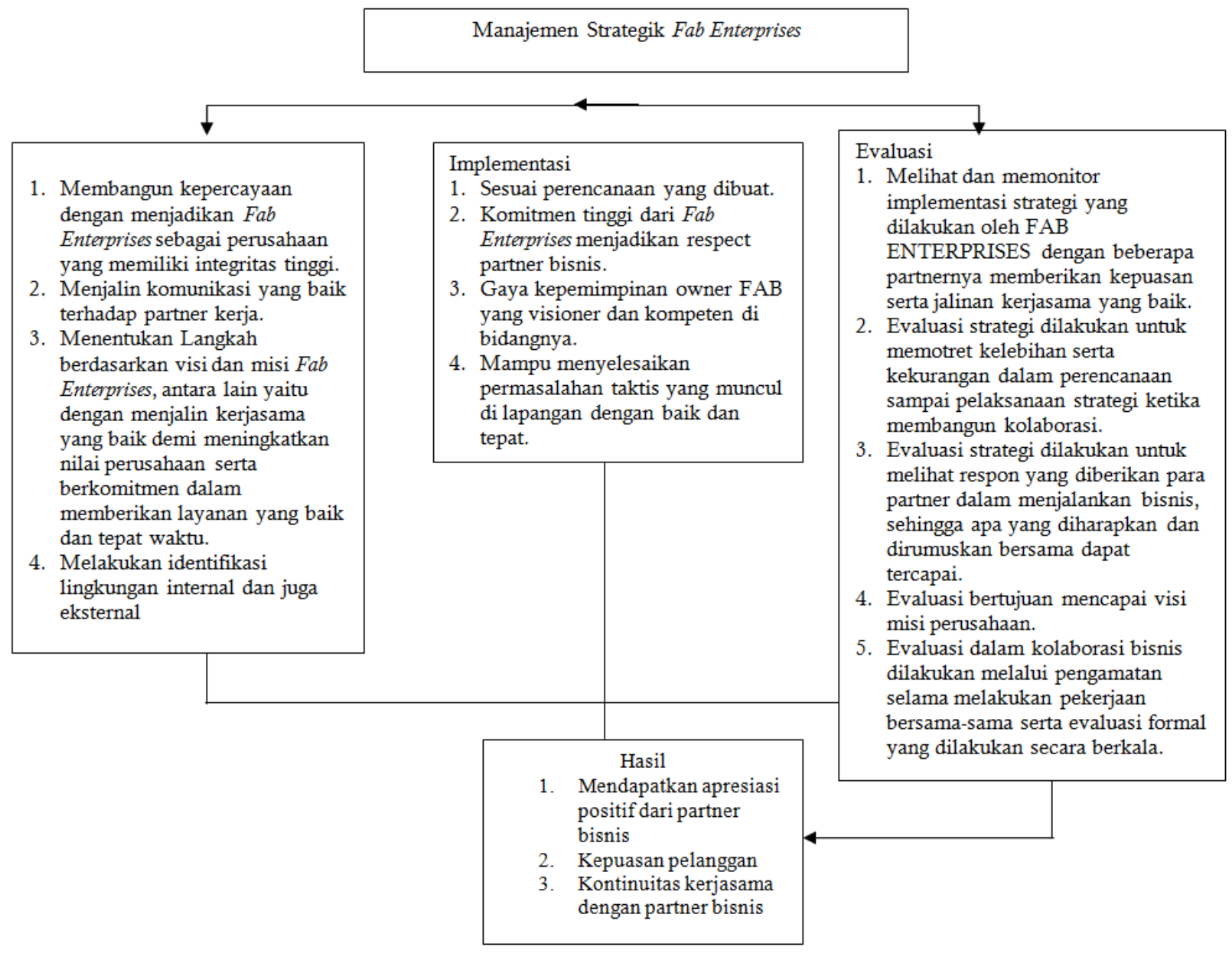

\section{Gambar 1. Hasil Penelitian}

Dari gambar tersebut peneliti terjun langsung ke lapangan untuk melakukan eksplorasi terhadap objek penelitian. Dengan memfokuskan pada tujuan mengenai yakni Manajemen Strategi FAB Enterprises dalam kolaborasi bisnis, serta faktor yang mempengaruhi dari objek penelitian, dimana objek dari penelitian ini adalah Pelayanan Logistik Pada Pendekatan kualitatif dipilih dengan tujuan untuk mendapatkan gambaran secara mendalam mengenai pengelolaan strategi yang dilakukan oleh Fab Enterprises dalam membangun jalinan kerjasama demi meraih suatu tujuan yang diharapkan. Sedangkan apabila ditinjau dari sifat-sifat datanya, maka penelitian ini termasuk ke dalam penelitian kualitatif (kualitatif research) atau naturalistik. Disebut kualitatif, karena sifat data yang dikumpulkannya bercorak kualitatif,bukan kuantitatif yang menggunakan alat-alat pengukur yang bermaksud untukmemahami fenomena tentang apa yang dialami oleh subjek penelitian misalnyaperilaku, persepsi, motivasi, tindakan dan lain-lain secara holistik, dan dengancara deskripsi dalam bentuk kata-kata dan bahasa, pada suatu konteks khususyang alamiah dan dengan memanfaatkan berbagai metode alamiah.

\section{Perumusan Strategi}

Empat point utama dalam perumusan atau perencanaan strategi yang dilakukan oleh Fab Enterprises adalah membangun kepercayaan dengan menjadikan Fab Enterprises sebagai perusahaan yang memiliki integritas tinggi, menjalin komunikasi yang baik terhadap partner kerja, menentukan Langkah berdasarkan visi dan misi Fab Enterprises, antara lain yaitu dengan menjalin kerjasama yang baik demi meningkatkan nilai perusahaan serta berkomitmen dalam memberikan layanan yang baik dan tepat waktu, melakukan identifikasi lingkungan internal dan juga eksternal. Pemilihan strategi yang cermat dan tepat merupakan hal yang sangat penting dalam mencapai harapan serta tujuan sebuah organisasi. Pemilihan strategi harus benar-benar dirumuskan 
dan dipertimbangkan sebaik mungkin. Perumusan strategi merupakan langkah awal dalam mengelola strategi. Perumusan strategi yang kurang tepat, akan berlanjut menjadi masalah dalam pelaksanaan dan evaluasi strategi. Rumusan strategi yang disusun Fab Enterprises dalam membangun hubungan kerjasama dengan beberapa perusahaan partnernya didasarkan pada analisis lingkungan internal maupun eksternal, dan didasarkan pada dialektika visi, misi, dan tujuan Fab Enterprises . Analisis lingkungan ini dimaksudkan untuk mengetahui tingkat kekuatan serta kelemahan yang dimiliki Fab Enterprises beserta partner sekaligus mengukur kekuatan dan kelemahan dari human system dan model kedua dipusatkan pada strategi manajemen (Kaye, 1994).

Indikator dari hasil analisis akan dijadikan dasar dalam pemilihan dan penyusunan strategi dalam membangun hubungan kerjasama. Hunger dan Wheelen (2003) menyampaikan bila, langkah pertama yang harus dilakukan dalam menyusun strategi untuk mencapai suatu tujuan adalah melakukan pengamatan atau identifikasi kondisi lingkungan internal maupun eksternal perusahaan, serta pemilihan dan penentuan strategi juga harus didasarkan pada apa yang menjadi visi, misi, dan tujuan perusahaan. David (2010) menyatakan bahwa langkah-langkah yang dilakukan dalam tahap perumusan strategi yaitu dengan melakukan identifikasi keadaan lingkungan internal dan eksternal perusahaan, melakukan pengembangan visi, misi, dan tujuan yang diinginkan perusahaan.

Pemilihan strategi pada tahap perumusan yang dilakukan Fab Enterprises dalam membangun kolaborasi dengan perusahaan partner kerjanya adalah melalui pembentukan kepercayaan serta menjalin komunikasi yang baik. Pembentukan kepercayaan ditunjukkan melalui kinerja FAB Fab Enterprises baik secara pribadi yang ditunjukkan oleh integritas owner maupun komitmen staf (Barata, Ujianto, dan Nanis, 2018). Sedangkan menjalin komunikasi yang baik dengan partner dan pengguna jasa dilakukan dalam bentuk gathering bersama yang diadakan oleh Fab Enterprises .

Perumusan strategi yang dilakukan oleh Fab Enterprises dalam komunikasi pemasaran sering disebut sebagai brand relationship. Menurut Percy (2008), brand relationship yang positif akan menghasilkan keuntungan dan terus meningkatkan nilai produk yang dijual oleh produsen. Fab Enterprises beserta partner melakukan brand relationship sehingga masing-masing menciptakan image positif dan berhasil meyakinkan para pengguna jasa hingga grafik kerjasama bisnis menjadi lebih baik. Komunikasi yang terintegrasi ini menguatkan banyak pihak dan mendatangkan respon positif dari para pengguna jasa. Keberhasilan merumuskan strategi Fab Enterprises yang pada mulanya berangkat dari visi misi sampai menjadi strategi bisnis bersama merupakan proses interaksi simbolik. Dimana interaksi simbolik secara sederhana didefinisikan sebagai langkah yang berhasil memberi makna yang dapat dimengerti oleh individu maupun subyek pelaku (Elbandiansyah, 2014).

\section{Implementasi Strategi}

Fab Enterprises dalam melakukan implementasi strategi terdapat empath al utama yang bisa dianalisis. Pertama implementasi dilakukan sesuai perencanaan yang dibuat, kedua komitmen tinggi dari Fab Enterprises menjadikan respect partner bisnis, ketiga gaya kepemimpinan owner Fab yang visioner dan kompeten di bidangnya, dan keempat mampu menyelesaikan permasalahan taktis yang muncul di lapangan dengan baik dan tepat.

Tahap kedua adalah penerapan strategi atau implementasi strategi. Tahap implementasi strategi sering kali dianggap tahap paling penting dan sulit dalam konsep manajemen strategi. Berhasil atau tidaknya penerapan konsep manajemen strategi akan dilihat dari berhasil atau tidaknya strategi itu diimplementasikan, meski sebenarnya ketiga tahapan manajemen strategi adalah sama-sama pentingnya. Perumusan strategi yang baik dan matang jika tidak diimplementasikan dengan baik maka hasil tidak baik juga. Perumusan strategi kurang baik, mustahil akan dapat dilaksanakan dengan baik. Perumusan strategi dan implementasi strategi dilakukan dengan baik, tapi tidak dievaluasi secara sungguh-sungguh maka hasilnya pun tidak akan maksimal. Artinya, bahwa tiga tahapan dalam manajemen strategi adalah saling berkaitan dan sama-sama pentingnya untuk dilakukan secara sungguh-sungguh.

Berdasarkan hasil temuan terkait implementasi strategi dalam membangun kolaborasi bisnis yang dilakukan Fab Enterprises dengan beberapa perusahaan partner kerjanya adalah dengan menunjukkan kinerja yang baik dan optimal. Untuk mengupayakan hal tersebut ownerFab Enterprises melakukan pengelolaan sumber daya secara efektif, termasuk dalam mengelola sumber daya manusianya, yaitu para tim kerja/karyawan. Jumlah dari anggota tim tidak terlalu banyak, akan tetapi dipilih atas kemampuan yang dimilikinya. Owner sebagai manajer perusahaan juga senantiasa terus memberikan motivasi-motivasi yang positif yang mampu mendorong semangat dalam bekerja. Salah satu cara yang dilakukannya adalah melalui gaya kepemimpinan yang diterapkannya. Dengan sikap yang baik, karakter pribadi yang positif, dapat dipercaya, menepati janji, serta memiliki kesesuaian antara perkataan, dan loyalitas terhadap para tim kerja, 
membuat para tim berada pada budaya kerja baik, sehingga mereka termotivasi untuk memberikan kinerja yang terbaik. Selain itu juga ditunjukkan dengan setiap pelaksanaan transaksi ada Standar Operasional Pelaksanaan (SOP)nya. Hal tersebut sebagai upaya meningkatkan kualitas kinerja dari masing-masing tim.

Implementasi strategi yang dilakukanFab Enterprises sebagaimana pendapat David (2010), bahwa penerapan strategi mengharuskan perusahaan untuk melakukan alokasi sumber daya, membuat kebijakan pelaksanaan strategi, termasuk menyusun standar operasional pelaksanaan, serta memotivasi para karyawan, sehingga strategi-strategi yang telah dirumuskan dapat dijalankan secara optimal. Terkait dengan kebijakan pelaksanaan strategi, Akdon (2016) menyebutkan bahwa kebijakan merupakan pedoman pelaksanaan tindakan-tindakan tertentu berdasarkan strategi pencapaian tujuan dan sasaran.

Peran penting owner Fab Enterprises sebagai leader dalam implementasi strategi sangat dominan dan penting. George Terry (1986) mengartikan kepemimpinan sebagai hubungan dimana satu orang yakni pemimpin mempengaruhi fihak lain untuk bekerja sama sukarela dalam usaha mengerjakan tugas-tugas yang berhubungan untuk mencapai yang diinginkan oleh pemimpin tersebut. Keberhasilan owner mengarahkan staf dan rekan bisnis dalam implementasi strategi bisnis tentunya didasari kemampuan manajerial owner Fab Enterprises yang bagus. Sebagaimana ditegaskan Robbins dalam Wuraji (2008) bila, kepemimpinan adalah kemampuan mempengaruhi suatu kelompok ke arah pencapaian tujuan. Implementasi tanpa kepemimpinan yang bagus tidak akan berhasil mengingat staf dan rekan bisnis memerlukan panduan dan bukti dari seorang pemimpin bagaimana melakukan implementasi rencana yang telah disusun.

\section{Evaluasi Strategi}

Evaluasi yang dilakukan oleh Fab Enterprises ada lima hal. Dimana yang pertama adalah melihat dan memonitor implementasi strategi yang dilakukan oleh Fab Enterprises dengan beberapa partnernya memberikan kepuasan serta jalinan kerjasama yang baik. Kedua, evaluasi strategi dilakukan untuk memotret kelebihan serta kekurangan dalam perencanaan sampai pelaksanaan strategi ketika membangun kolaborasi. Ketiga, evaluasi strategi dilakukan untuk melihat respon yang diberikan para partner dalam menjalankan bisnis, sehingga apa yang diharapkan dan dirumuskan bersama dapat tercapai. Keempat, evaluasi bertujuan mencapai visi misi perusahaan. Kelima, evaluasi dalam kolaborasi bisnis dilakukan melalui pengamatan selama melakukan pekerjaan bersama-sama serta evaluasi formal yang dilakukan secara berkala.

Implementasi strategi yang suskes menuntut adanya pelaksanaan evaluasi strategi. Pada tahap evaluasi ini, akan dapat dilihat apakah pelaksanaan strategi sudah sesuai dengan rumusan strategi yang telah disusun sebelumnya. Melalui pelaksanaan evaluasi juga akan dapat diketahui permasalahan-permasalahan yang terjadi dalam membangun kolaborasi bisnis. Dari keseluruhan hasil evaluasi akan dijadikan dasar dalam melakukan perbaikan-perbaikan jika memang dirasa perlu dalam membangun kolaborasi bisnis yang baik dengan perusahan-perusahaan partnernya.

Evaluasi strategi yang dilakukan oleh Fab Enterprises dalam membangun kolaborasi bisnis dengan perusahaan partner kerjanya adalah dengan melalui pengamatan/monitoring selama pelaksanaan program kerja. Evaluasi juga dilakukan secara formal dan berkala. Dari hasil evaluasi akan dapat diketahui sejauh mana jalinan kerjasama yang dibangun, serta permasalahan-permasalahan apa saya yang telah muncul, sehingga dari hasil tersebut akan dijadikan sebagai acuan untuk melakukan tindak lanjut sebagai bentuk perbaikan.

Pelaksanaan evaluasi ini sebagaimana pendapat David (2010), bahwa dalam proses evaluasi strategi, ada tiga aktivitas yang dilakukan yaitu mengkaji ulang terhadap strategi-strategi yang sudah dirumuskan, mengukur hasil kinerja, dan mengambil tindakan atau langkah sebagai koreksi. Hasil evaluasi strategi menunjukkan bahwa adanya kepercayaan yang kuat serta adanya jalinan komunikasi yang baik dari perusahaan partner dalam membangun kolaborasi bisnis dengan FAB ENTERPRISES . Terbukti adanya kepuasan dalam menjalin hubungan kerjasama dan hubungan tersebut survive sampai saat ini.

Fab Enterprises dalam evaluasi strategi menerapkan Total Quality Management yang menurut Santoso dalam Tijptono dan Anastasia (1998) merupakan sistem manajemen yang mengankat kualitas sebagai strategi usaha dan berorientasi pada kepuasan pelanggan dengan melibatkan seluruh anggota organisasi (Tjiptono dan Anastasia, 1998). Tjiptono dan Anastasia (1998) menyatakan Total Quality Management merupakan suatu pendekatan dalam menjalankan usaha yang mencoba untuk memaksimumkan daya saing organisasi melalui perbaikan terus menerus atas produk, jasa, manusia, proses dan lingkungannya. Langkah evaluasi penting dilakukan untuk mengetahui dan mengontrol pelaksanaan strategi apakah sesuai dengan perencanaan atau timbul dialektika di dalamnya. Ketika terjadi dialektika antara perencanaan dan kenyataan, maka muncul rekomendasi-rekomendasi yang mengarah pada perbaikan kinerja Fab Enterprises beserta partner. 
Evaluasi strategi yang dilakukan Fab Enterprises dalam perspektif budaya organisasi bisa dijelaskan sebagai bentuk kegiatan yang rutin dilakukan untuk perbaikan perusahaan. Wirawan (2007) mendefinisikan budaya organisasi sebagai norma, nilai, yang dikembangkan oleh pendiri untuk diterapkan dalam aktifitas organisasi dalam memproduksi dan melayani konsumen. Dalam konteks evaluasi strategi yang dilakukan Fab Enterprises Leslie and Byars (2003) merumuskan empat bentuk budaya organisasi yang salah satunya sesuai dengan keadaan Fab Enterprises yakni bet you company culture. Dimana setiap person dalam Fab Enterprises beserta rekan terbiasa mengambil resiko dalam pekerjaan. Akan tetapi resiko terburuk sudah diantisipasi dengan pembuatan perencanaan strategi yang matang. Sehingga dapat meminimalisir kesalahan yang fatal dan dapat menjaga mutu jasa yang diberikan kepada pengguna.

\section{Simpulan}

Kesimpulan dalam artikel ini adalah, owner Fab Enterprises telah melakukan pengelolaan strategi untuk dapat membangun hubungan kerjasama yang baik dengan para perusahaan partner kerjanya.strategi dalam membangun kolaborasi bisnis yang dilakukan Fab Enterprises dengan beberapa perusahaan partner kerjanya adalah dengan menunjukkan kinerja yang baik dan optimal. Untuk mengupayakan hal tersebut ownerFab Enterprises melakukan pengelolaan sumber daya secara efektif, termasuk dalam mengelola sumber daya manusianya, yaitu para tim kerja/karyawan. Jumlah dari anggota tim tidak terlalu banyak, akan tetapi dipilih atas kemampuan yang dimilikinya. Owner sebagai manajer perusahaan juga senantiasa terus memberikan motivasi-motivasi yang positif yang mampu mendorong semangat dalam bekerja. Salah satu cara yang dilakukannya adalah melalui gaya kepemimpinan yang diterapkannya. Dengan sikap yang baik, karakter pribadi yang positif, dapat dipercaya, menepati janji, serta memiliki kesesuaian antara perkataan, dan loyalitas terhadap para tim kerja, membuat para tim berada pada budaya kerja baik, sehingga mereka termotivasi untuk memberikan kinerja yang terbaik. Selain itu juga ditunjukkan dengan setiap pelaksanaan transaksi ada Standar Operasional Pelaksanaan (SOP)nya. Hal tersebut sebagai upaya meningkatkan kualitas kinerja dari masingmasing tim.Hal ini dimaksudkan untuk meningkatkan jaringan kerja sama sebagai upaya dalam mencapai visi, misi, dan tujuan perusahaan. Tiga langkah pengelolaan strategi yang dilakukan, diawali dengan melakukan perumusan strategi, dimana tahap perumusan strategi ini didasarkan pada analisis lingkungan internal dan eksternal serta didasarkan pada pencapaian visi, misi, dan tujuan perusahaan. Berdasarkan hal tersebut, strategi yang dimunculkan adalah membangun kepercayaan kepada partnernya dan menjalin komunikasi yang baik. Tahap selanjutnya adalah implementasi strategi, hal ini didasarkan pada pengelolaan/alokasi sumber daya yang efektif, memberikan motivasi kepada para tim/karyawan, dan pelaksanaan strategi didasarkan pada SOP. Terakhir adalah tahap evaluasi strategi, yaitu dengan melakukan pengamatan/monitoring terhadap kinerja. Dari hasil evaluasi menunjukkan adanya kepercayaan yang kuat dan jalinan komunikasi yang baik antara Fab Enterprises dengan perusahaan partnernya sehingga kolaborasi tetap terjalin sampai saat ini serta membuahkan hasil kepuasan pengguna jasa.Evaluasi strategi yang dilakukan oleh Fab Enterprises dalam membangun kolaborasi bisnis dengan perusahaan partner kerjanya adalah dengan melalui pengamatan/monitoring selama pelaksanaan program kerja. Evaluasi juga dilakukan secara formal dan berkala. Dari hasil evaluasi akan dapat diketahui sejauh mana jalinan kerjasama yang dibangun, serta permasalahan-permasalahan apa saya yang telah muncul, sehingga dari hasil tersebut akan dijadikan sebagai acuan untuk melakukan tindak lanjut sebagai bentuk perbaikan.

\section{Referensi}

Akdon, (2016). Strategic Management: For Educational Management. Bandung: Alfabeta.

Arikunto, Suharsimi. (2012). Prosedur Penelitian: Suatu Pendekatan Praktik. Jakarta: Rineka Cipta.

Barata, Fausta Ari, H. Ujianto and Nanis Susanti (2018). Determinants of Trust Establishment Success in Business Relationship (Case Study of Fab Enterprises ): -www.journalijar.com Article DOI:10.21474/IJAR01/8018, 450-465.

Bleeke, Joel, David Ernst, (1993). The Death of the Predator, in Bleeke, Joel and David Ernst (ed), Collaborating to Compete: Using Strategic Alliances and Acquistions in the Global Marketplace. New York: John Willey and Sons. Inc.

Bogdan, Robert C. et.al., (2006). Qualitatif Research for Education: and Introduction to Theory and Methods. London: Allyn \& bacon Inc.

Bryson, John S. and Other, (2006). The Design and Implementation of Cross-Sector Collaborations: Propositions from the Literature. Public Administration Review. December 2006. Special Issue.

Creswell, John W, (2014). Penelitian Kualitatif dan Desain Riset: Memilih Diantara Lima Pendekatan. Jogjakarta: Pustaka Pelajar. 
David, Fred R, (2014). Strategic Management, Manajemen Strategis Konsep. Terj. Dono Sunardi, Edisi 12, Jakarta: Salemba Empat.

Dwiyanto, Agus, (2011). Manajemen Pelayanan Publik: Peduli, Inklusif dan Kolaboratif: Edisi Kedua. Yogyakarta: Gadjah Mada University Press.

Elbandiansyah dan Umiarso, (2014). Interaksionisme Simbolik, Jakarta: Rajagrafindo Persada

Genera, (2009). Corporation Buillding the Collaborative Enterprise: Ten Questions to Ask about Bussines Opportunities through Collaborations.

Hunger, David J. dan Thomas L. Wheelen, (2003). Manajemen Strategis. terj. Julianto Agung S, Cet. 16, Yogyakarta: Andi.

Huxham, Chris and Siv Vangen, (1996). Key Themes in the Management to Relationship Between Public and Non Profit Organizations. The International Journal of Public Sector Management (IJPSM) Vol 9. No. 7.

Jauch, Lawrence R. dan Wiliam F. Gluech, (2011). Manajemen Strategis dan Kebijakan Perusahaan. Jakarta: Erlangga.

Kaye, Michael, (1994). Communication Management. Sydney: Prentice Hall.

Kim, Maurborgne, (2006). Blue Ocean Strategy (Strategi Samudra Biru): Ciptakan Ruang Pasar Tanpa Pesaing dan Biarkan Kompetisi Tak Lagi Relevan. Jakarta: Penerbit Serambi.

Leslie, W. Roe and Lloyd L. Byars, (2003). Management Skill and Application, New York: Mc Graw-Hill Irwin.

Mark A. Hager and Tyler Curry, (2009). Models of Collaborations: Non Profit Organizations Working Together. ASU Lodestar Center.

Milles, Mattew B., A. Micheke Haberman, (1992). An Expanded Sourcebook Qualitative Data Analysis, Terj. Tjetjep R. Rohidi, Analisis Data Kualitatif. Jakarta: UI Press.

Nawawi, Hadari, (2005). Manajemen Strategi Organisasi Non Profit Bidang Pemerintahan dengan Ilustrasi di Bidang Pendidikan. Cet. III, Yogyakarta: Gadjah Mada University.

Prasetio, Bambang, (2005). Metodologi Penelitian Kualitatif. Jakarta: PT. Raja Grafindo Persada.

Riyanto, Yatim, (2001). Metodologi Penelitian Pendidikan. Surabaya: SIC.

Siswanto, (2005). Pengantar Manajemen. Jakarta: Bumi Aksara.

Sudjana, H.D, (2000). Manajemen Program Pendidikan untuk Pendidikan Luar Sekolah dan Pengembangan Sumber Daya Manusia. Bandung: Falah Production.

Sugiyono, (2014). Metode Penelitian Kuantitatif Kualitatif dan R\&D. Bandung: Alfabeta.

Syairozi, M. I. (2021). Analisis Kemiskinan di Sektor Pertanian (Studi Kasus Komoditas Padi di Kabupaten Malang). Media Ekonomi, 28(2), 113-128.

Syairozi, M. I. (2019). Keterkaitan Variasi Produk dan Tenaga Kerja Terhadap Peningkatan Laba Bengkel Ahas Pandaan.

Thomson, Ann Marie and Miller, (2002). Knowledge for Practice: The Meaning and Measurement of Collaboration. Canada: Paper presented at the 2002 ARNOVA

Thomson, Ann Marie and James L. Perry, (2006). Collaboration Processes: Inside the Black Box. Paper Presented on Public Administration Review: Academic Researc Library.

Terry, George R. (1986). Asas-Asas Manajemen, Terj. Winardi. Bandung: Alumni.

Tjiptono, Fandy dan Anastasia Diana, (1998). Total Quality Manajemen (TQM), Yogyakarta: Andi Ofset.

Wirawan, (2007). Budaya dan iklim organisasi, Jakarta: Salemba.

Wuradji, (2008). The Educational Leadership, Kepemimpinan Transformasional. Yogyakarta: Gama Media. 